\title{
FORMATION HISTORY OF THE PRINCIPLES \\ OF THE PUBLIC ADMINISTRATION, MECHANISMS OF THEIR MANIFESTATION, AND THEIR CURRENT USAGE
}

\section{Hromova O. V.}

\section{INTRODUCTION}

The appearance, development, functioning and cessation of existence of any system is due to certain consistent patterns of an objective nature. If we consider a human body as a biological system, such consistent patterns are easy to detect - it is the birth of a person, their development in time (physical improvement, aging, etc.), their death.

All other known systems, including the public administration system, are no exception to this rule.

The research objective is to determine the theoretical knowledge of the principles of public administration, the formation of the mechanism of their manifestation and use.

\section{Presentation of the results of the study}

The principles as theoretical concepts reflect the essence and reality of the processes of public administration, subject to certain laws.

The principles of public administration are its positive characteristics, known in science and practice, fixed in legal regulations or presented as generalization of current legal rules in the state.

There are also other definitions provided in scientific literature. For example, the principles of public administration are the fundamental bases, the guidelines that determine the crucial rules, under which management is implemented and organized ${ }^{1}$.

Principles are specific terms, the content of which is not so much the pattern, the relationship, the interrelation, as our knowledge of them. They are the result of the generalization of objectively valid laws and patterns, common features, specific facts and characteristics by people,

1 Принципи державного управління: поняття, види та їхня характеристика. URL: http://studies.in.ua/admin-pravo-shpora/2908-principiderzhavnogo-upravlnnya-ponyattya-vidi-ta-yihnya-harakteristika.html (дата звернення: 15.02.2020). 
that become the common basis of their activity. The principles of administration have two main features:

a) belonging to the known in science and practise positive patterns;

b) being fixed in the public consciousness (relevant concepts).

In practice, the principles of public administration are applied in accordance with the political, socio-economic and cultural conditions prevailing in society. The public administration principles justify, clarify the links between the object and the subject of the administration, as well as within each of them. They reflect the features of the management system as a whole, as well as of its individual elements, phenomena, processes. The principles represent the content and interconnections of the key elements of the management system. The principles of public administration are dynamic in content and form; they are shaped by people in connection with specific political, socio-economic and cultural factors, reflecting the degree of creative use of the public administration regularities.

Directly in practice, the principles of management take a form of norms, rules that are applied in management activities. The flexibility and dynamism of the principles of public administration is also manifested in the fact that in each specific area of activity, their specific principles of management functions are formed.

In the search for an optimal system for public administration, the problem of defining the principles of public administration is extremely important.

The scientific understanding and theoretical substantiation of the principles of public administration proceed from the analysis of the essence of the phenomenon itself.

Scholars name a different number of principles, such as H. Fayol 14, H. Emerson - 12, F. Taylor - 10, M. Weber - 7, L. Urwick $-6^{2}$.

One of the first researchers to attempt to systematize the principles of management was the French engineer and scientist H. Fayol. His management system was based on the administrative doctrine.

2 Принципи державного управління. Державне управління : підручник : у 2 т. / Нац. акад. держ. упр. при Президентові України ; ред. кол. : Ю.В. Ковбасюк (голова), К.О. Ващенко (заст. голови), Ю.П. Сурмін (заст. голови) та ін. Київ ; Дніпропетровськ : НАДУ, 2012. Т. 1. С. 108-117. URL: http://academy.gov.ua/NMKD/library_nadu/Pidruchnuiky_NADU/5d5407e7f2ef-4ec4-8f8a-42c075c9ffc9.pdf (дата звернення: 21.02.2020). 
Based on it, the scientist has identified fourteen principles of administrative activity: division of labor, authority and responsibility, discipline, unity of leadership, unity of management, subordination of personal interests to the general, reward, centralization, hierarchy (scalar chain), order, fairness, staff stability, initiative, corporate spirit.

These principles, supplemented by the functions of the personnel in the organization, defined the specialization, hierarchy, control frameworks and fundamentals of the organizational structure as the basis on which the organizations are formed and management tasks are carried out.

G.V. Atamanchuk points out that the process of revealing and justifying the principles of public administration must meet the following requirements ${ }^{3}$ :

a) reflect not just any, but only the most essential, main, objectively necessary patterns, relations and interrelations of public administration;

b) characterize only the regular patterns, relations and interrelations in public administration;

c) cover predominantly such patterns, relations and interrelations that are inherent to government as an integral social phenomenon, that is, are of a general rather than a partial nature;

d) reflect the specifics of public admnistration, its difference from other types of administration.

Thus, the concept of "principle of public administration" intends, first in a scientific and later in a legal form, to reflect the patterns that objectively exist in public administration and which are of particular importance for its organization and implementation.

The principles of public administration are fundamental truths, positive patterns, guiding ideas, basic provisions, norms of behavior, reflecting the laws of development of management relations, formulated in the form of a certain scientific provision, fixed mainly in the legal form, on the basis of which the apparatus of public administration is built and operates.

Principles define requirements to the system, structure, organization and process of management, directions and limits of management decision-making. When characterizing any given principle, one should take into account its relationship with, and dependence on, other

3 Атаманчук Г.В. Государственное управление (организационнофункциональные вопросы) : учебное пособие. Москва : ОАО «НПО «Экономика», 2000. 302 с. 
principles. The principles interact with each other within a coherent system, balancing or reinforcing each other, enabling each other to sufficiently disclose their nature, individuality and regulatory capabilities.

Upon that, each principle has its structurally assigned place, which gives grounds to conclude - the full disclosure of the content and potential of any principle of public administration is possible only within the framework and taking into account its system dependencies.

Thus, princilples of public administration must:

- be based on the laws of the development of a society, its social and economic laws and public administration laws;

- meet the goals of management, reflect the main qualities, connections and relationships of management;

- take into account the temporal and territorial aspects of public administration processes.

First of all, we will start with the principle of knowledge transfer and the principle of all-purposeness of management. The latter states that there are management functions common for public and private management. This enables us, analyzing a number of problems of public administration in Ukraine and the application of public administration technologies, to apply the relevant groundwork of management science, first of all the principles given below.

Almost all scholars who study problems of management theory and practice as a phenomenon, and in particular of public administration, consider the classification of principles.

The classic classification of principles of public administration:

- socio-political,

--organizational,

- organizational-political,

- organizational-technical,

- economic,

- organizational-legal,

- general-essential,

- specific,

- general,

- separate,

- socio-political,

-functional-structural,

- organizational-structural, 
- principles of state- management activities.

In today's context, in our view, it is advisable to highlight the following gradation of the principles of public administration.

1 Administrative-legal principles of public administration: compliance with objective laws of social development; publicity of legal regulation; compliance with the interests of the people; objectivity from the standpoint of law enforcement; correlation between government and public administration; legal regulation of management activities.

2 System-target principles of public administration: separation of powers between the subjects of public administration horizontally and vertically; subordinating local goals to a common goal; consistency of goals with each other; complementarity of goals; consistency in achieving the totality of goals; distribution of goals by public administration functions.

3 System-functional principles of public administration: fixing the division of functions by legal norms; compatibility of functions of public authorities; differentiation of special (specific) functions; concentration of the same functions in the respective bodies; combining related functions within one body; correspondence of actual activity to the assigned functions.

4 System-organizational principles of public administration: unity of the system of public authorities; territorial-branch organization of management; a variety of organizational connections; conformity of elements of activity of organs (methods, forms, stages) to their place in the hierarchical structure; delegation of authority and responsibility; a combination of unity and collegiality; linear-functional (staff) construction of the management structure.

5 Adaptive principles of public administration: clarification of purpose in the change of circumstances; conformity of elements of the system to a specific purpose; focus on continuous updating; setting standards for system elements; taking into account the pace of development of managed objects in the formation of management decisions; specification of management activities and personal responsibility; strengthening the social protection of civil servants.

Among the most well-known general management principles are those concerning the rational organization of any processes, the universality of management, the goal-setting and the expediency of the management structure. 
Types of principles of public administration: administrative-legal, system-targeted, system-functional, system-organizational, adaptive.

The basic principles of rational organization of any processes include: proportionality (provision of resources according to the capacity of different jobs); continuity; directness (characterizes the optimality of the path of the subject of managerial work, information); rhythmicity (uniformity of execution of processes in time); concentration of homogeneous items of work; flexibility. Among these principles should also be mentioned those smoothing resource requirements (concurrency and reduction of work intensity).

For management systems, determination, complexity and scientific validity (defining the best ways and means to achieve goals) should also be added to the principles of rational organization of any process. From the point of view of system control, the principle of division into subsystems is worthy of consideration, according to which, if the links between subsystems are less developed than the links within them, the division into subsystems can be natural and clear.

Universal management principles relate to the rationalization of the personnel management system, organization and its structure. They were distinguished by representatives of the classical (administrative) school of management by F. Taylor, H. Fayol, H. Emerson, L. Gulick, L. Urwick, R. Falk, and M. Weber.

The generalization and development of these principles are provided in the works of S. O'Donnell, V. Knorring, G. Kunz, V.I. Kudin, and Yu.I. Palekha ${ }^{4}$.

In our paper we consider the most significant of them.

The principle of self-organization of systems is used in the study of the real least studied objects and processes, with public administration rightly attributed to them.

Since society is a dissipative system, a synergistic theory can also be applied to the analysis of its development. The self-organization of a social system means the change of its structure at the expense of its own driving forces in order to achieve a state of equilibrium and efficient functioning. Self-organization is based on the desire of organizations to provide a variety of reactions to external influences necessary for the conscious realization of the achievement of its goals.

${ }^{4}$ Палеха Ю.І. Ключі до успіху, або Організаційна та управлінська культури. Київ : Вид-во Європ. ун-ту фінансів, інформ. систем, менеджменту і бізнесу, 2000. $211 \mathrm{c}$. 
The principle of self-organization is one of the two basic principles of coordination in social systems, along with the principle of governance (the choice of coordinating influence in a fixed governance structure). According to the latter, management, in contrast to functioning, which is related to the preservation of past experience, is primarily associated with the acquisition of new experience. The principle of management is the rules for moving to a new state of the object of management, and the principle of operation is the rules for ensuring the necessary functioning of the object of management in each of its states.

In practice, both principles are taken into account, which are complementary and do not ensure the development of the system in themselves.

The most important in terms of achieving certain states of a control entity is the feedback principle, which allows it to adjust the management process to achieve the stated goals by analyzing the development of the situation (through the control function). In public administration this principle is formulated as the principle of control. One of its forms is the coordination of decisions. Its another modification is the principle of control over critical points, i.e. the facts that are critical to assess the degree of implementation of plans. It should be remembered that control is generally justified only when deviations from the plans are adjustable.

The principle of resource conservation implies a general approach whereby the resolution of problems, including management problems, is achieved at the minimum cost of available resources (human, information, financial, material, time). This principle is becoming global due to the significant reduction of the earth's natural resources against the background of high population growth.

For as long as management exists, for so long the problem of its optimality, that is, the best choice in a particular situation, is being solved. This is the principle of optimality of management. For social systems, optimality of management has the meaning of the most desirable control, the best of all possible ones. It is a minimized, costeffective activity aimed at achieving the desired result, below the threshold of which is the sphere of inefficient, undesirable result. In practice, the principle of optimality is to develop and apply new techniques, procedures and management technologies to find ways and methods to improve the effectiveness of management activities.

The principle of relevance of information states that increasing the amount of information does not proportionally improve the quality of 
decisions, so it is necessary to separate relevant information about a particular problem from another. Since relevant information is the basis of decisions, it is necessary to achieve its maximum accuracy and relevance to the problem, that is, to apply information filters.

Modern management uses the principle of a single entry of information, the essence of which is that once entered into the computer's memory, the information is repeatedly used to solve numerous management tasks. This principle contributes to the creation of databases and knowledge bases, the development of information technology, electronic communications networks.

The principle of social responsibility, unlike legal liability, allows a certain level of voluntary response to social problems by organizations. Such a response is beyond statutory requirements, defined by law or regulatory bodies.

This principle is still not commonly used in Ukraine and it is not only the fault of organizations. It is important not to reduce the capacity of organizations to solve social problems, but to expand them, and not with outdated, but with new approaches and ways to improve the social protection of workers.

An important place among the general management principles belongs to the group of principles of goal setting.

The principle of unity of objectives, management and responsibility is, in fact, a prerequisite for the life of any organizational system. Its implementation in the public administration system is associated with a clear definition of the goals and functions of the authorities, the construction of their organizational structures, the division of tasks, powers and responsibilities between them.

The goal limitation principle provides for narrowing down the range of problems being solved through their better understanding and quality solutions. It focuses on achieving the greatest efficiency and performance in a limited field, and only then on shifting to a wider range of problems. In practice, the application of this principle promotes the professionalism of government officials, gaining of experience in solving management problems, finding the most effective methods and techniques for forming management decisions.

This principle is also identified with the principle of selectivity, the essence of which, in the opinion of the American scientist C. Barnard, is the need to distinguish those facts that significantly affect the achievement of the goals of the organization and those that do not play a 
significant role. For example, it is advisable to identify strategic factors for the functioning of institutions and organizations ${ }^{5}$.

Another principle, the principle of specifity and measurability of a goal - requires that for each goal there are certain criteria that would allow you to evaluate the degree of achievement of the goal. If there is no such criteria, the realization of one of the crucial management functions - control, is impossible.

Therefore, even for the unstructured problems inherent to social systems, more or less acceptable criteria must be found.

The hierarchic nature of organization building and management systems, as well as the widespread use of program and target management, including analytical programming and project management methods, make it particularly important to study and implement the principles of building "goal trees". The latter are a set of rules that provide:

- consideration of different alternatives of goals;

- removal of unimportant, ineffective activities and activities with insufficient resources;

- moving to lower-level goals only after completing a qualitative description, expanding over time, and determining the coefficients of relative importance of higher-level goals.

Among the general principles of a efficient management structure, we will consider the following: compliance of management units with its functions; minimizing the number of steps (links) in the management hierarchy; focusing on every step of all the necessary management functions; the concentration of functional links in the functional units; a clear allocation of the participation of each functional link in a whole management process; elimination of duplication of functions; minimizing the flow of commands from each management link.

In modern management practice, the principle of specialization is widely used, according to which organizations and units are separated by their characteristics. This leads to the formation of target and functional bodies.

In the process of forming new units, it is advisable to adhere to the principle of their adaptation, that is, subordination for a certain period of

Закономірності, принципи та чинники вибору в науковому пізнанні процесів управління. URL: http://megalib.com.ua/content/9779_Zakonomirnosti_ principi_ta_chinniki_vibory_v_naykovomy_piznanni_procesiv_derjavnogo_ypravlin nya.html (дата звернення: 01.04.2020). 
formation to one of the higher authorities in order to protect against pressure from other units.

In the work of organizations, it is also important to be committed to the principle of institutional identity, the essence of which is in accordance with the formal and informal structures of the organization, both its general goals and current objectives.

To reduce the dependence of the organization on the personal qualities of its members, as a rule, the principle of formalization of procedures is implemented. At the same time, American scientist F. Selznick warned against the hasty formalization of procedures at the primary stage of formation of organizations, when the threat of isolation of management from other workers emerges, when such contacts are most needed.

The well-known principles of an ideal bureaucratic organization of management, proposed by the prominent German scientist M. Weber, namely: the activity of the organization is divided into elementary operations; the tasks and responsibilities of each link are formalized; experts are recruited on condition of full responsibility for the efficient and effective execution of tasks; the organization is built on the principle of hierarchy; the organization's activities are governed by a system of rules and standards that ensure the uniformity of each task by the executors; functioning of the organization in accordance with rational standards eliminates the possibility of interference with personal considerations and emotions; service in a bureaucratic organization is based on the qualification of the concordance of the position held; employees are protected from non-motivated dismissal; there is a system of promotion under certain conditions of work record and successful activity. Most of the above-mentioned principles are still relevant today and are fundamental to the human resource management system, particularly at the state level.

In the processes of public administration, the human factor is central. Professionalism, activity, initiative, innovation, morality - these are just some of the parameters and manifestations of this factor. Today, professionalism is impossible without knowledge of modern principles of management activity.

We turn to a number of well-known decision-making principles, as well as the relevant starting points - postulates that can always be useful when considering management situations and preparing certain decisions, namely: 
- people are significantly different in the intensity and nature of their willpower and their means of solving problems (the principle of individuality);

- it is difficult to make good decisions (the principle of good decisions);

- it is not enough to just have skills and desires, appropriate conditions need to be created (the principle of sufficient conditions);

- the alternative may be subject, relation or action (the principle of the diversity of forms of alternative);

- the decision-making process is intuitive, judgment-based, or rational in nature, and decision-making methods, in turn, range from spontaneous to high-tech (the principle of diversity in decision-making);

- accurate calculation backed by experience and intuition leads to success (the principle of professionalism);

- the subjective probability estimation determines the choice of decision-making strategy (the principle of subjective probability);

- decisions are to be made with consideration of all factors, including undesirable ones (the principle of compromise);

- in some cases elimination of decision-making is a good choice (the principle of timeliness);

- the decision-making model should be adequate to the situation, that is, consistent with the structure and properties of the management entity, the requirements of the management task, the values and preferences system of the decision-maker, their professional level (the principle of adequacy).

The principle of quality management of decisions implies the setting of standards, open communication, implementation and at the same time prevention of excessive control, introduction of scientific approaches, motivation and modeling methods. This is one of the basic principles of modern management, directly aimed at improving the effectiveness of management decisions.

Providing sufficient control flexibility can be achieved with the principle of the degree of freedom of the decision, which presupposes the degree of admissibility of variability of a certain decision, that has system connections with other decisions, primarily the decisions of higher levels of management.

The principle of authority delegation is widely used in the public administration and involves the transfer of responsibilities and powers to the official who takes responsibility for their performance. This principle ensures management effectiveness if decisions are made within the 
authority of each employee, rather than being redirected to higher organizational levels. Executives, especially upper levels of management, often neglect this principle, while reducing the managerial potential of the organization.

To manage, one must not only know well, but also apply the principles of managing people. Among the latter there are the following:

- support for self-esteem in subordinates; attention to problems, not to personalities;

- encouragement for the honest execution of the manager's instructions;

- formulation of clear and reasonable requirements;

- bringing tasks in line with the performer's intellectual and physical abilities;

- achieving a balance of authority and responsibility of the performer, as well as motivation and contribution (the principle of participation, defined by H. Simon);

- maintenance of constant contacts, feedbacks with subordinates.

There are specific principles that apply directly to the organization of the manager's work.

For example, the principle of unanimity requires that an employee receives orders from only one direct supervisor. The better the relationship of the subordinate with the manager is, the less likely they are to receive contradictory instructions and the deeper the sense of personal responsibility for the results of the work is.

In accordance with the principle of the first leader in the execution of important tasks, control remains with the first head of the organization, as only he has the right and ability to decide or delegate the solution of any issue.

On the principle of functional definition, the more clearly the directions and expected results of activity, powers, position and information connections are defined, the bigger contribution to the realization of the goals of the organization should be expected.

By the scalar principle, the clearer the line of communication of the manager with each of the subordinates, the more effective the decisionmaking and communication processes.

It is also advisable to outline the principle of leadership, when the manager or the governing body which is the first to start using new scientific advances is more likely to succeed and to be the leader.

The basic principles of public administration and approaches to their systematization have been thoroughly considered in numerous works of 
modern domestic and foreign scientists. Here are just the ones that have the greatest influence on government decision making.

The principle of objectivity of public administration necessitates the observance of the requirements of objective laws and real capabilities of the public forces in the governmental processes. It needs to be studied, in particular when researching the process of public administration in Ukraine, these patterns, careful analysis of existing political forces, the real economic and political potential of the state, the social situation of the majority of the population, as well as conducting constant monitoring of all major processes taking place in the state.

The principle of advanced management state provides for the transition from orientation to the past (planning based on the achieved) to the orientation towards the future. This is the tendency inherent in modern Ukraine and reflected in its main programmatic documents. The state of advance in public administration implies the widespread use of modern scientific results by its subjects, the search for optimal management decisions, the concentration of highly qualified specialists with the appropriate competence level in the field of management, the orientation of management to the needs of society and its development prospects.

The principle of democracy reproduces rule of the people, namely: it defines the role of the people as a carrier and a source of power, which it realizes both directly through referenda and the electoral system, and indirectly through state authorities and local self-government. This principle involves the protection of fundamental human rights and freedoms, political and ideological pluralism, the rule of law, the realization of the idea of sociality ${ }^{6}$.

The principle of separation of powers presupposes the division of power into three branches - legislative, executive and judicial. It promotes a system of checks and balances in power and prevents the establishment of an undemocratic regime, and is usually established in the constitutions of countries, for example, like it is in Ukraine.

The principle of legality provides for the priority of the law and is aimed at creating strong legal foundations in all spheres of the state. It stipulates the necessity of predominantly legislative definition of the main goals, functions, structures, processes, and principles of public administration. This principle is directly related to the principle of legal

6 Державне управління як система принципів. URL: http://ru.osvita.ua/ vnz/reports/law/10530/ (дата звернення: 19.02.2020). 
protection of administrative decisions, that is, their adoption on the basis of knowledge of the current legislation and only with consideration of their compliance with applicable legal acts.

The principle of optimization of management dictates the need to reduce sectoral hierarchical levels of government, the regulatory role of the state apparatus, which restrains the autonomy and initiative of organizations, improving the structure of management and work motivation. Such measures, especially in the context of increasing demand for management, observed in Ukraine, should be taken moderately based on sound structural changes to the new strategic goals of the state.

Structural principles of public administration are a set of principles that are systematized as follows: structurally-targeted, reflecting the patterns of rational construction of the "goal tree" of public administration; structurally-functional, characterizing patterns and interconnections of building a functional structure of public administration; structurally-organizational, which are related to the patterns and interconnections of building the organizational structure of public administration; structurally-procedural, which give an idea of the basic patterns of rational, effective and efficient management of government and local self-government.

The general principles of public administration also include the principle of unity of economy and policy, while maintaining the priority of the latter, as well as the principle of combining general and local interests with the priority of higher-level interests.

Governance principles are closely linked to the laws of government. We can consider this as exemplified in the following control laws:

- unity of the management system;

- the combination of centralization and decentralization;

- the interdependence of the object and the subject of management;

- distribution of management work;

- compliance of authority with responsibility;

- purposefulness of construction and operation of the management system;

- the exclusive role of human creative activity in the organization of quality management system.

Thus, it is advisable to distinguish the following groups of principles of public administration:

1) socio-political: democracy, participation of the population in the administrative activity of the state (nationality); equality of persons of 
different nationalities; equality of all before the law; legitimacy; publicity and consideration of public opinion; objectivity.

One of the most important conditions for the successful construction of a democratic, constitutional and social state is ensuring the real participation of citizens in solving all the diversity of issues in state and public life. That is why the participation of the population in the governmental activity of the state is an indispensable principle of public administration, established in the Constitution, laws of Ukraine and many regulations.

A special place among all principles of public administration belongs to the principle of legality. Article 1 of the Constitution defines Ukraine as a rule of law, Article 8 establishes the rule of law as a state principle, and Articles 6 and 19 establish that the legislative, executive and judicial branches of power exercise their powers within the limits established by this Constitution and in accordance with the laws of Ukraine. This means strict and steady adherence to laws and regulations;

2) organizational principles of building the apparatus of state administration: sectoral, functional, territorial.

The branch principle is implemented in such a structural construction, where objects that are homogeneous in nature are assigned to the relevant governing body and form the sphere of its management activity. It is customary to name subjects that exercise sectoral government control sectoral government bodies.

The territorial principle is evident in the structural construction under which state authorities carry out complex management in certain clearly defined territories;

3) organizational principles of functioning (activity) of the apparatus of public administration: normalization of activity, unity, collegiality, division of administrative work; responsibility for decisions, operational independence.

Organizational principles of functioning (activity) of the apparatus of public administration are applied to determine the content of activity of specific administrative structures. Adherence to these principles enables the most effective use of the potential of civil servants, staff of research institutions, and technical staff. These principles ensure the right management decisions, the organization and implementation of sound management procedures, effective control and executive discipline. They are recorded in the relevant regulations.

The principle of normalization is used for the legal regulation of the activity of the public administration apparatus. 


\section{CONCLUSIONS}

The principle of unanimity is that a public authority is headed by a certain person appointed to a position by the adoption of a management act. Thus, in accordance with Articles 106 and 114 of the Constitution of Ukraine and Clause 7 of the General Regulation on the Ministry, the other central body of the state executive power (approved by the Decree of the President of Ukraine of March 12,1996) is headed by a minister appointed by the President of Ukraine upon submission by the Prime Minister of Ukraine. The Minister directs the areas of activity entrusted to him.

The principle of collegiality involves discussing important issues by teams of professionals whose opinions should be taken into account when making decisions. The general regulation on the ministry, another central body of the state executive power contains a norm according to which a panel should be formed for collective discussion of the most important directions of the activity of the ministry and development of the branch. In addition, a scientific-technical (scientific) council, as well as other advisory and consultative bodies may be formed to consider scientific recommendations, discuss programs, and other issues within the ministry.

The application of the principle of separation of management labor is due to the fact that the latter consists of relatively independent homogeneous species, each of which requires subjects of certain qualifications and specific knowledge, that is, managerial specialization. Therefore, teams of specialists are formed within the governing bodies, which can be organized in the form of headquarters, departments, subdivisions, sectors, etc. The governing document that reflects this principle is staffing.

The principle of accountability for decisions is twofold. First of all, its application ensures the inevitability of responsibility for wrong decisions made without consideration of objective laws and specific situations, and second of all, the responsibility is personified on its basis.

The implementation of the principle of operational independence is essential for the successful implementation of public administration. All the diversity of management activities cannot be foreseen and established in the documents governing the functioning of the governing bodies. The complexity of the issues being solved necessitates the analysis of a considerable amount of information and the availability of many specialists of diverse competence. At the same time, the dynamics of socio-economic processes encourages civil servants to make prompt 
decisions. Therefore, the state, defining and fixing the administrative and legal norms of the competence of the governing bodies, gives them the appropriate opportunities and operational space for independent action.

\section{SUMMARY}

The research deals with the issues of forming the principles of public administration, the mechanism of their manifestation and use. This is relevant when the country has been under the influence of legislative reforms over the last few years, which in one way or another affect the overall structure of state power.

The works of well-known scientists, on which the whole scientific space is based, are considered. The features and characteristics that are inherent to the principles of public administration are identified. Namely, the fact that they acquire the nature of norms, rules, which are guided in management activities. The flexibility and dynamism of the principles of public administration is manifested in the fact that in each specific sphere of activity, their qualitative principles of management functions are formed.

Knowledge of the historical origin and formation of principles of public administration, mechanisms of their manifestation and use will help in the future to create an effective system of public administration of the country.

\section{REFERENCES}

1. Принципи державного управління: поняття, види та їхня характеристика. URL: http://studies.in.ua/admin-pravo-shpora/2908principi-derzhavnogo-upravlnnya-ponyattya-vidi-ta-yihnyaharakteristika.html (дата звернення: 15.02.2020).

2. Принципи державного управління. Державне управління : підручник : у 2 т. / Нац. акад. держ. упр. при Президентові України ; ред. кол. : Ю.В. Ковбасюк (голова), К.О. Ващенко (заст. голови), Ю.П. Сурмін (заст. голови) та ін. Київ ; Дніпропетровськ : НАДУ, 2012. Т. 1. С. 108-117. URL: http://academy.gov.ua/ NMKD/library_nadu/Pidruchnuiky_NADU/5d5407e7-f2ef-4ec4-8f8a42c075c9ffc9.pdf (дата звернення: 21.02.2020).

3. Атаманчук Г.В. Государственное управление (организационно-функциональные вопросы) : учебное пособие. Москва : ОАО «НПО «Экономика», 2000. 302 с. 
4. Палеха Ю. І. Ключі до успіху, або Організаційна та управлінська культури. Київ : Вид-во Свроп. ун-ту фінансів, інформ. систем, менеджменту і бізнесу, 2000. 211 с.

5. Закономірності, принципи та чинники вибору в науковому пізнанні процесів управління. URL: http://megalib.com.ua/ content/9779_Zakonomirnosti_principi_ta_chinniki_vibory_v_naykovo my_piznanni_procesiv_derjavnogo_ypravlinnya.html (дата звернення: 01.04.2020).

6. Державне управління як система принципів. URL: http://ru.osvita.ua/vnz/reports/law/10530/ (дата звернення: 19.02.2020).

7. Мельтюхова H.M. Закони та принципи державного управління. URL: http://www.kbuapa.kharkov.ua/e-book/apdu/20091/doc/1/05.pdf (дата звернення: 19.02.2020).

\section{Information about author: Hromova O. V.,}

Ph.D. in Economics, Associate Professor, Associate Professor of the Department of Management and Administration Ukrainian State University of Railway Transport 7, Feiierbakh Square, Kharkiv, 61000, Ukraine 